\title{
Monthly forage value of various plant organs of Brocchia cinerea from a Moroccan arid region
}

\author{
NISRINE CHLIF ${ }^{1, \bullet}$, MOHAMMED DIOURI ${ }^{2}$, MOHAMMED EL OMARI ${ }^{1}$, AMAR BENTAYEB ${ }^{1}$ \\ ${ }^{1}$ Team of Physical-Chemistry of Condensed Matter, Department of Chemistry, Faculty of Sciences, Moulay Ismail University. BP. 11201 Zitoune \\ Meknes, Morocco. Tel.: +212-636250593, `email: nisrin.chliff@gmail.com \\ ${ }^{2}$ Laboratory of Plant Biotechnologies and Molecular Biology, Department of Biology, Faculty of Sciences, Moulay Ismail University. BP. 11201 Zitoune \\ Meknes, Morocco
}

Manuscript received: 27 July 2021. Revision accepted: 10 December 2021.

\begin{abstract}
Chlif N, Diouri M, El Omari M, Bentayeb A. 2021. Monthly forage value of various plant organs of Brocchia cinerea from a Moroccan arid region. Biodiversitas 23: 67-74. Brocchia cinerea Vis (Asteraceae) represents a xerophytic botanical species widely used in South-Eastern Morocco as a potential animal feed. The present study was aimed to investigate the chemical profile, as well as the in vitro dry matter digestibility (IVDMD), and to estimate the net energy for lactation (NEl) of some fractions (flowers, leaves, stems, and browsable aerial part (whole part a $10 \mathrm{~cm}$ above the ground) of $B$. cinerea. The ether extract (EE) content of some plant parts varied between 0.43 and $1.89 \%$. As far as, the highest concentration of crude protein (CP) was found in leaves. The maximal values for neutral detergent fiber (NDF), acid detergent fiber (ADF), and acid detergent lignin (ADL) were found in the mature stems with $58.63 \%, 44.87 \%$, and $13.05 \%$, respectively. The leaves were the richest fraction in essential oil (EO), total phenols (TP), and tannins. Furthermore, the IVDMD values of various fractions of plants ranged between 59.56 to $89.43 \%$. The assessed NEl was highest during cold months in some fractions of young plants and decreased with maturity. In conclusion, B. cinerea has a good nutritive value, especially in leaves and early stages.
\end{abstract}

Keywords: Chemical analysis, digestibility, feed, grazing, livestock

\section{INTRODUCTION}

Pastures located in drylands are an important feed resource for grazing ruminants. Animal products obtained in such systems are generally characterized by specific sensory properties; and it is important to maintain these pastures to preserve environmental biodiversity (Distel et al. 2020; Martin et al. 2005).

Livestock uses about half of the global surface area. It provides several goods and services across the world. This is through a variety of animal species and resources provided by an extensive range of agro-ecological and socio-economic conditions (Herrero et al. 2013). The livestock industry is an important and integral part of the agriculture sector in Morocco. Livestock farming is vital for the supply of meat and milk and also a source of additional income for small farmers and livestock owners (Bettencourt et al. 2015; McAdams et al. 2019).

Decreased cost and increased efficiency of production have long been goals of producers. With increased feed and other farm expenses, pasture is being reexamined as a method to reduce the cost of production. Profitable milk and meat production from pasture depends on many factors, including forage availability, intake, and nutritional quality, and the supplemental feed provided. The nutritional value of pasture changes during the grazing season and presents a challenge for a farmer to provide proper supplementation (Hoffman et al. 1993).

The pasture quality may change rapidly, and a rapid analysis may be needed to adjust the supplemental feeding program to provide an adequate supply of nutrients for high production (Hoffman et al. 1993). Over the past few decades, the search for alternative feeds has rekindled research interest in the use of spontaneous plants in arid areas as sources of nutrients for livestock (Amata and Lebari 2011; Chlif et al. 2021; Nsubuga et al. 2019). In the pastoral drylands, numerous species of herbaceous naturally growing are known to be widely used in livestock production. Quite often, they are grazed by animals or mown and fed either as fresh or conserved fodders. The utilization of these and many other herbs growing naturally within the farm environment is rather opportunistic. Therefore, it becomes necessary to understand the nutritional dynamics of forage to sustain adequate growth and reproduction of livestock (Ganskopp and Bohnert 2001; Farrukh and Jan Durrani 2009).

The present study aimed to evaluate the nutritional value of some parts of the Brocchia cinerea Vis (Asteraceae) plant and monitor the changes in these values with plant maturity.

\section{MATERIALS AND METHODS}

\section{Plant material}

Brocchia cinerea was chosen because it is widespread in south-eastern Moroccan rangelands, especially in winter. The representative samples of fodder were harvested from H'ssia (Alnif, Tinghir, Draa-Tafilalet) at different 
phenological stages from February to June 2019. The study site falls within the semiarid zone at altitude $500 \mathrm{~m}$ a.s.l. It is between $31^{\circ} 7^{\prime}$ north and $5^{\circ} 6^{\prime}$ west. The aerial part of the whole plant was cut at the base, $10 \mathrm{~cm}$ above the ground. Leaves, flowers, and stems were separated manually, constituting individual fractions beside the whole aerial part. The browsable aerial part of this plant was also studied because it is an actual consumable part.

\section{Chemical analysis}

The four various fractions of $B$. cinerea were dried at room temperature $\left(28 \pm 2{ }^{\circ} \mathrm{C}\right)$, ground, and passed through a $1.0 \mathrm{~mm}$ screen using a laboratory mill. Dry Matter (DM) and Ash content were determined according to AOAC (1990). Ether extract (EE) content was determined with the ANKOM XT15 analyzer according to AOCS (2005). Crude Protein (CP) was determined by the micro-Kjeldahl method (Nelson and Sommers 1972).

Neutral Detergent Fiber (NDF), Acid Detergent Fiber (ADF) and Acid Detergent Lignin (ADL) were determined by the Van Soest method using the filter bags (Komarek et al. 1994). The essential oils (EO) were extracted by hydrodistillation using a Clevenger. Determination of total phenols was carried out according to Borneo et al. (2009). Total tannins and condensed tannins were determined according to Lawrence et al. (1986) and Makkar et al. (1993), respectively. True digestibility (IVDMD) of $B$. cinerea plant dry matter was evaluated in vitro by DAISYII ${ }^{\circledR}$ incubator (ANKOM Technology). Forage energy value was represented by the net energy for lactation (NEl), which was estimated according to NRC (2001).

\section{Statistical analysis}

Data were analyzed by XLSTAT (2019) version 4.2. The means values were compared by Tukey's test (HSD). The level of significance was determined at $\mathrm{p}<0.05$. In a second time, data underwent a two-way ANOVA, including month, fraction, and their interaction, and using R (R Core Team 2020).

\section{RESULTS AND DISCUSSIONS}

Intensive grazing has proven itself as a popular and economical alternative to feeding cattle through the spring and summer months. However, profitable production from pasture is dependent upon the quantity and nutritional quality of the forage available for grazing (Oredice et al. 2019; Rivero et al. 2019). Producing suitable quality forage for a given situation requires knowing factors that affect forage quality such as the species of dominant herbage (Capstaff and Miller 2018), the physiological state of the sward and the weather (Da Silva et al. 2015). Analyzing forages for nutrient content can be used to determine whether the quality is adequate and to guide proper ratio supplementation (Ball et al. 2001).
Generally, in this study, there were wide variations in the chemical composition of the investigated different parts of B. cinerea (leaves, flowers, stems and aerial part) collected on various development stages.

\section{Chemical composition \\ Dry matter (DM)}

The dry matter content of all the studied fractions (flowers, leaves, stems and aerial part) of the plant increased non-significantly with time (Table 1).

There was an increasing trend of DM from February towards June in all the analyzed fractions, as well as the highest DM values were observed for leaves. Variation of DM content could be due to the time of sampling and environmental effects as the climatic temperature of the study region.

\section{Ash content (ash)}

In this analysis, high ash contents were found in the leaves followed by the aerial parts of the plant and stems. However, the minimum values were observed in flowers especially at the reproductive stage (February) (Table 1). These results were similar to that shown by Deinum and Dirven (1976) for two grasses Brachiaria ruziziensis and Setaria sphacelata, whose leaves ash (11.4 and 9.4\%) were higher than total plants (10.4 and 8.7\%) and stems (9.5 and $8.4 \%$ ), respectively.

Generally, the ash content values were low at the first harvest, which progressively increased with the advancing of plant maturity. The differences between ash contents of different plant parts were statistically significant $(\mathrm{P}<0.05)$ at all harvest months (Table 1).

This increase of ash was similar to that reported by Azim et al. (1989) and Tilahun et al. (2017), who observed an increase in ash with the advanced phenological stage of plants. The high ash contents observed at the last harvest months can be attributed to the climatic effect and to high temperatures inherent in arid regions, which cause plants to lose all their green and tender parts (Walthall et al. 2012). This variation of ash contents may also be due to features that need to be explored, such as the age of foliage, internal nutrient balance, effects of diseases, type and age of soil (Farrukh and Jan 2009).

\section{Ether extract (EE)}

According to these findings, the differences between $\mathrm{EE}$ of various plant parts were non-significant at all harvest months (Table 1). The highest levels of EE were observed in the leaves in February and April, as well as the lowest EE values were obtained in stem fractions. The EE mean in the other studies shows that leaves could be a good source of energy that can be used by ruminants for body maintenance and production (Berhe and Tanga 2013).

Generally, as the plant matured, the EE concentration of the various fractions declined, reaching the lowest levels in summer. 
Table 1. Monthly content of DM, ash, EE and CP in different fractions of Brocchia cinerea (mean $\pm \mathrm{SD})$

\begin{tabular}{|c|c|c|c|c|c|}
\hline Harvest month & Plant fraction & $\% \mathrm{DM}$ & $\%$ Ash & $\% \mathrm{EE}$ & $\% \mathrm{CP}$ \\
\hline \multirow{4}{*}{ February } & $\mathrm{Fl}$ & $26.52 \pm 1.94^{\text {bcde }}$ & $3.66 \pm 0.14^{\mathrm{ab}}$ & $0.85 \pm 0.22^{\mathrm{abc}}$ & $8.44 \pm 0.63^{\text {defg }}$ \\
\hline & Lv & $29.71 \pm 1.03^{\text {cde }}$ & $7.24 \pm 0.93^{\mathrm{efg}}$ & $1.89 \pm 0.23^{\mathrm{e}}$ & $12.17 \pm 1.38^{\mathrm{i}}$ \\
\hline & St & $17.81 \pm 2.42^{\mathrm{a}}$ & $5.37 \pm 0.76^{\text {bcdef }}$ & $0.62 \pm 0.19^{\mathrm{a}}$ & $4.11 \pm 0.14^{\mathrm{abc}}$ \\
\hline & $\mathrm{AP}$ & $26.27 \pm 2.96^{\mathrm{bcd}}$ & $6.23 \pm 0.78^{\text {bcde }}$ & $0.98 \pm 0.24^{\text {abcde }}$ & $8.97 \pm 1.07^{\mathrm{defgh}}$ \\
\hline \multirow[t]{4}{*}{ March } & $\mathrm{Fl}$ & $27.23 \pm 1.30^{\text {bcde }}$ & $4.21 \pm 0.88^{\mathrm{a}}$ & $0.83 \pm 0.21^{\mathrm{abc}}$ & $8.17 \pm 0.27^{\text {defg }}$ \\
\hline & Lv & $32.57 \pm 1.32^{\text {efg }}$ & $8.06 \pm 1.35^{\mathrm{fg}}$ & $1.51 \pm 0.12^{\text {cde }}$ & $11.64 \pm 0.39^{\mathrm{hi}}$ \\
\hline & St & $21.21 \pm 0.43^{\mathrm{ab}}$ & $5.52 \pm 1.06^{\text {cdefg }}$ & $0.60 \pm 0.17^{\mathrm{a}}$ & $3.56 \pm 0.28^{\mathrm{ab}}$ \\
\hline & $\mathrm{AP}$ & $27.74 \pm 1.8^{\mathrm{bcd}}$ & $7.42 \pm 0.38^{\text {cdefg }}$ & $1.09 \pm 0.19^{\text {abcde }}$ & $8.13 \pm 0.17^{\mathrm{def}}$ \\
\hline \multirow[t]{4}{*}{ April } & $\mathrm{Fl}$ & $29.48 \pm 2.59^{\text {cde }}$ & $5.75 \pm 0.86^{\mathrm{efg}}$ & $0.64 \pm 0.12^{\mathrm{ab}}$ & $7.28 \pm 0.55^{\mathrm{de}}$ \\
\hline & $\mathrm{Lv}$ & $37.56 \pm 1.23^{\mathrm{g}}$ & $7.33 \pm 0.48^{\text {defg }}$ & $1.75 \pm 0.32^{\mathrm{de}}$ & $11.28 \pm 1.51^{\mathrm{ghi}}$ \\
\hline & St & $24.55 \pm 1.64^{\mathrm{abc}}$ & $7.2 \pm 0.81^{\text {cdefg }}$ & $0.56 \pm 0.23^{\mathrm{a}}$ & $3.73 \pm 0.17^{\mathrm{abc}}$ \\
\hline & $\mathrm{AP}$ & $33.19 \pm 0.32^{\text {efg }}$ & $8.62 \pm 0.86^{\text {cdefg }}$ & $1.13 \pm 0.24^{\mathrm{abcd}}$ & $8.45 \pm 1.03^{\text {defg }}$ \\
\hline \multirow[t]{4}{*}{ May } & $\mathrm{Fl}$ & $29.51 \pm 1.32^{\text {cde }}$ & $5.39 \pm 0.11^{\mathrm{abc}}$ & $0.75 \pm 0.09^{\mathrm{a}}$ & $6.74 \pm 0.22^{\text {cde }}$ \\
\hline & $\mathrm{Lv}$ & $36.81 \pm 1.16^{\mathrm{fg}}$ & $7.34 \pm 1.44^{\mathrm{defg}}$ & $1.46 \pm 0.13^{\text {bcde }}$ & $10.52 \pm 0.29^{\text {fghi }}$ \\
\hline & St & $21.52 \pm 1.90^{\mathrm{ab}}$ & $6.21 \pm 1.67^{\mathrm{feg}}$ & $0.43 \pm 0.11^{\mathrm{a}}$ & $3.81 \pm 1.46^{\mathrm{abc}}$ \\
\hline & $\mathrm{AP}$ & $30.35 \pm 1.18 \mathrm{c}^{\mathrm{def}}$ & $7.52 \pm 0.63^{\text {cdefg }}$ & $0.91 \pm 0.25^{\mathrm{abcd}}$ & $7.63 \pm 0.29^{\mathrm{def}}$ \\
\hline \multirow[t]{4}{*}{ June } & $\mathrm{Fl}$ & $28.60 \pm 1.74^{\mathrm{cde}}$ & $6.80 \pm 0.15^{\mathrm{abcd}}$ & $0.61 \pm 0.04^{\mathrm{a}}$ & $6.15 \pm 1.38^{\mathrm{bcd}}$ \\
\hline & Lv & $37.04 \pm 1.87^{\mathrm{fg}}$ & $9.71 \pm 1.27^{\mathrm{efg}}$ & $0.82 \pm 0.17^{\mathrm{abc}}$ & $9.82 \pm 0.47^{\text {efghi }}$ \\
\hline & St & $23.32 \pm 1.70^{\mathrm{bcd}}$ & $8.11 \pm 0.48^{\mathrm{g}}$ & $0.51 \pm 0.25^{\mathrm{a}}$ & $2.61 \pm 0.34^{\mathrm{a}}$ \\
\hline & $\mathrm{AP}$ & $30.69 \pm 2.43^{\text {defg }}$ & $7.82 \pm 0.93^{\text {cdefg }}$ & $0.63 \pm 0.11^{\mathrm{a}}$ & $5.84 \pm 0.11^{\mathrm{abc}}$ \\
\hline
\end{tabular}

Note: Means within a column lacking a common superscript differ ( $\mathrm{p}<0.05)$. Fl: Flower; Lv: Leave; St: Stem; AP: Aerial part, DM: Dry matter; EE: Ether extract; CP: Crude protein

Crude protein $(C P)$

In this result, $\mathrm{CP}$ content was higher in leaves than in other fractions of the plant. However, the lowest values of the $\mathrm{CP}$ were found in the stems. The $\mathrm{CP}$ proportion in various plant parts declines as the plant matures. Significant differences $(\mathrm{P}<0.001)$ were observed in the values of $\mathrm{CP}$ in various plant parts (Table 1). Bouallala et al. (2011) reported that $B$. cinerea plant collected at the flowering stage in the Northwest of Algerian contains $4.42 \pm 0.30 \%$ which was a low value compared to those obtained in this study. CP content of $B$. cinerea was superior to that of Aristida plumose (6.54\%), Zilla spinosa (5.22\%) and Aristida pungens (4.09\%) (Longo-Hammouda et al. 2007), as well as, they are inferior to that of Maize (Azim et al. 1989), Alfalfa and Timothy (Ball et al. 2001).

Generally, CP concentration was high in February (reproductive stages) than at other months relating to growth stages. A decrease of CP percentage in a plant, with time, was related to the reduction of leaf-to-stem ratio and is a major cause of the decline in plant quality with maturity (Chaudhary et al. 2012; Ferreira et al. 2018).

Leaves were higher in quality than stems, and the proportion of leaves in forage declined as the plant matured (Ball et al. 2001). This agrees with Ganskopp and Bohnert (2001) who also reported high CP contents during spring and lowest in late September. Xie et al. (2012) and Etse et al. (2018) reported that $\mathrm{CP}$ content was higher during the early growth and decreased with maturity.

Plants need more nitrogenous food for vegetative growth and therefore in the early stages of their growth, proteins are stored so that they are consumed during flowering and fruiting, in which nutritional status decreases. Animal health might decline with a reduction in the availability of protein in plants. They need protein to maintain their growth and reproduction (Farrukh and Jan
2009).

\section{Fiber analysis}

Regardless of the season, NDF, ADF, and ADL concentrations in stems were higher than in other plant organs (Table 2).

Table 2. Cell wall constituents of different parts of Brocchia cinerea at five harvest months (mean $\pm \mathrm{SD}$ )

\begin{tabular}{|c|c|c|c|c|}
\hline $\begin{array}{l}\text { Harvest } \\
\text { month }\end{array}$ & $\begin{array}{l}\text { Plant } \\
\text { fraction }\end{array}$ & $\%$ NDF & $\%$ ADF & $\%$ ADL \\
\hline \multirow[t]{4}{*}{ February } & $\mathrm{Fl}$ & $22.84 \pm 1.31^{\mathrm{a}}$ & $14.64 \pm 0.88^{\mathrm{a}}$ & $3.89 \pm 0.36^{\mathrm{a}}$ \\
\hline & $\mathrm{Lv}$ & $30.49 \pm 2.05^{\mathrm{bc}}$ & $21.08 \pm 0.12^{\mathrm{abc}}$ & $4.04 \pm 0.59^{\mathrm{a}}$ \\
\hline & St & $40.76 \pm 1.61^{\text {fgh }}$ & $28.64 \pm 0.03^{\text {abcde }}$ & $8.49 \pm 0.73 \mathrm{f}^{\text {ghi }}$ \\
\hline & $\mathrm{AP}$ & $36.46 \pm 0.72^{\text {cde }}$ & $22.18 \pm 0.28^{\mathrm{abcd}}$ & $6.85 \pm 0.14^{\text {bcde }}$ \\
\hline \multirow[t]{4}{*}{ March } & $\mathrm{Fl}$ & $28.68 \pm 1.36^{\mathrm{ab}}$ & $20.03 \pm 0.06^{\mathrm{ab}}$ & $3.60 \pm 0.72^{\mathrm{ab}}$ \\
\hline & $\mathrm{Lv}$ & $33.51 \pm 1.27^{\mathrm{bc}}$ & $24.95 \pm 0.12^{\text {bcdef }}$ & $5.21 \pm 0.15^{\mathrm{abc}}$ \\
\hline & St & $46.59 \pm 1.8^{\mathrm{hj}}$ & $39.64 \pm 6.20^{\text {ghi }}$ & $10.24 \pm 0.66^{\mathrm{hi}}$ \\
\hline & $\mathrm{AP}$ & $35.81 \pm 1.18^{\mathrm{cd}}$ & $28.57 \pm 0.65^{\text {defgh }}$ & $5.72 \pm 1.18^{\text {bcde }}$ \\
\hline \multirow[t]{4}{*}{ April } & $\mathrm{Fl}$ & $37.09 \pm 1.23^{\mathrm{de}}$ & $22.93 \pm 0.94^{\text {abcde }}$ & $5.93 \pm 0.51^{\mathrm{abcd}}$ \\
\hline & Lv & $36.24 \pm 0.26^{\mathrm{cd}}$ & $25.86 \pm 1.48^{\text {bcdef }}$ & $5.86 \pm 0.36^{\mathrm{abcd}}$ \\
\hline & St & $49.91 \pm 0.25^{\mathrm{i}}$ & $35.83 \pm 0.89^{\mathrm{ghi}}$ & $12.51 \pm 0.43^{\mathrm{ij}}$ \\
\hline & $\mathrm{AP}$ & $41.20 \pm 1.21^{\mathrm{efg}}$ & $29.68 \pm 0.67^{\mathrm{efgh}}$ & $6.88 \pm 0.19^{\text {defgh }}$ \\
\hline \multirow[t]{4}{*}{ May } & $\mathrm{Fl}$ & $37.59 \pm 1.43^{\mathrm{def}}$ & $30.12 \pm 0.46^{\text {defgh }}$ & $6.69 \pm 0.73^{\text {bcde }}$ \\
\hline & Lv & $36.97 \pm 0.16^{\mathrm{de}}$ & $27.95 \pm 2.49^{\text {cdefgh }}$ & $7.28 \pm 0.15^{\text {cdefg }}$ \\
\hline & St & $51.99 \pm 0.10^{\mathrm{i}}$ & $40.47 \pm 1.36^{\mathrm{i}}$ & $11.79 \pm 0.36^{\mathrm{j}}$ \\
\hline & AP & $43.57 \pm 0.98^{\mathrm{gh}}$ & $31.42 \pm 1.92^{\text {fghi }}$ & $7.41 \pm 0.51^{\mathrm{efgh}}$ \\
\hline \multirow[t]{4}{*}{ June } & $\mathrm{Fl}$ & $35.13 \pm 0.98^{\mathrm{cd}}$ & $25.97 \pm 0.14^{\text {bcdef }}$ & $7.10 \pm 1.01^{\text {cdef }}$ \\
\hline & $\mathrm{Lv}$ & $40.84 \pm 1.65^{\mathrm{de}}$ & $23.66 \pm 0.18^{\text {cdefg }}$ & $7.63 \pm 0.67^{\text {cdefg }}$ \\
\hline & $\mathrm{St}$ & $58.63 \pm 2.38^{j}$ & $44.87 \pm 0.61^{\mathrm{j}}$ & $13.05 \pm 0.59^{i j}$ \\
\hline & $\mathrm{AP}$ & $46.05 \pm 1.16^{\mathrm{ghi}}$ & $31.95 \pm 2.78^{\mathrm{hi}}$ & $9.64 \pm 0.65^{\text {ghi }}$ \\
\hline
\end{tabular}

Mean values within columns with different superscripts differ significantly $(\mathrm{P}<0.05)$. Fl: Flower; Lv: Leave; St: Stem; AP: Aerial part; NDF: Neutral detergent fiber; ADF: Acid detergent fiber; ADL: Acid detergent lignin 


\section{Neutral detergent fiber (NDF)}

Results of cell wall content showed that there was an increasing trend of NDF from February towards June month in all the analyzed parts of a plant, while stems fraction was contained the highest NDF concentration followed by aerial part, leaves and flowers, respectively. NDF concentration was also strongly influenced by plant maturation $(\mathrm{P}<0.001)$.

The results agree with other studies of Ganskopp and Bohnert (2001) and Sultan et al. (2007) which reported an increase in NDF concentration with a maturity of plants. Lee (2018) also reported that NDF of plants was positively related to phenology, as both NDF and ADF were affected by plant age.

\section{Acid detergent fiber $(A D F)$}

NDF contents differed significantly $(\mathrm{P}<0.001)$ between various plant fractions and between various harvest months $(\mathrm{P}<0.01)$. The results revealed that the ADF concentration of stems was highest in all harvest months. The maximum values of ADF in leaves and flowers were observed in May with a minor decline in June month. For the aerial part of $B$. cinerea, ADF concentration increases as the plant get old to reach its maximum in June.

Compared with a study carried out by Farrukh and Jan (2009), whose NDF, ADF, and ADL content of Artemisia maritima, and Hertia intermedi were higher than those found in $B$. cinerea at the reproductive stage, but they were lower in the post-reproductive stage.

\section{Acid detergent lignin (ADL)}

The present study shows that ADL value was significantly greater $(\mathrm{P}<0.001)$ in stems than in other parts of the plant, a maximum of ADL was observed at the last harvest (June). The rate and extent of increases in ADL concentration in leaves and flowers were substantially less than in stems and aerial parts of a plant. Similarly, Azim et al. (1989) and Sultan et al. (2007) also reported that lignin contents increase with age and cause a corresponding decrease in the nutritive value. The results agree with other studies of Ganskopp and Bohnert (2001), Sultan et al. (2007) and Velásquez et al. (2019) which reported an increase in NDF, ADF and ADL concentration with a maturity of plants.

Annual plant $B$. cinerea completes its life cycle within a few months, which could be the reason that this species quickly ends up with high NDF, ADF and ADL concentrations.

\section{Anti-nutritional substances}

The richness of various fractions studied of $B$. cinerea in essential oils, total polyphenols, total tannins and condensed tannins contents was reflected in Table 3 .

Results of essential oil (EO) yield indicated that there was an increase from February (first harvest) to June (last harvest) as the plant matured. The leaves fraction was contained the highest EO concentration followed by aerial parts and flowers, respectively. However, the stems were devoid of EO. The EO yield of different plant parts varied non-significantly with maturity.

Table 3. Anti-nutritional substances contents of different parts of Brocchia cinerea at five harvest months (mean $\pm \mathrm{SD}$ )

\begin{tabular}{|c|c|c|c|c|c|}
\hline $\begin{array}{l}\text { Harvest } \\
\text { month }\end{array}$ & $\begin{array}{c}\text { Plant } \\
\text { fraction }\end{array}$ & $\begin{array}{l}\text { EO } \\
(\%)\end{array}$ & $\begin{array}{c}\text { TP } \\
\text { (mg GAE/g DM) }\end{array}$ & $\begin{array}{c}\text { TT } \\
(\mathrm{mg} \mathrm{TAE} / \mathrm{g} \text { DM) } \\
\end{array}$ & $\begin{array}{c}\text { CT } \\
(\mathrm{mg} \mathrm{CE} / \mathrm{g} \text { DM) }\end{array}$ \\
\hline \multirow[t]{4}{*}{ February } & $\mathrm{Fl}$ & $0.11 \pm 0.02^{\mathrm{a}}$ & $10.56 \pm 0.16^{\mathrm{bc}}$ & $4.92 \pm 0.23^{b c}$ & $0.95 \pm 0.16^{\mathrm{abc}}$ \\
\hline & Lv & $0.26 \pm 0.12^{\mathrm{bcd}}$ & $31.43 \pm 074^{\text {hi }}$ & $11.05 \pm 0.54^{\mathrm{gh}}$ & $2.08 \pm 0.3^{\mathrm{abcd}}$ \\
\hline & St & - & $5.62 \pm 0.55^{\mathrm{a}}$ & $2.45 \pm 0.37^{\mathrm{a}}$ & $0.53 \pm 0.21^{\mathrm{ab}}$ \\
\hline & $\mathrm{AP}$ & $0.20 \pm 0.03^{\mathrm{abc}}$ & $26.42 \pm 0.62^{\mathrm{g}}$ & $6.03 \pm 0.37^{\mathrm{cd}}$ & $1.83 \pm 0.22^{\mathrm{abcd}}$ \\
\hline \multirow[t]{4}{*}{ March } & $\mathrm{Fl}$ & $0.18 \pm 0.02^{\mathrm{ab}}$ & $15.87 \pm 0.24^{\mathrm{de}}$ & $6.36 \pm 0.21^{\mathrm{cde}}$ & $0.63 \pm 0.17^{\mathrm{a}}$ \\
\hline & Lv & $0.24 \pm 0.01^{\mathrm{bc}}$ & $35.03 \pm 0.14^{j}$ & $12.32 \pm 0.50^{\mathrm{h}}$ & $2.46 \pm 0.55^{\text {bde }}$ \\
\hline & St & - & $8.11 \pm 0.23^{\mathrm{ab}}$ & $3.41 \pm 0.47^{\mathrm{ab}}$ & $0.69 \pm 0.12^{\mathrm{ab}}$ \\
\hline & $\mathrm{AP}$ & $0.23 \pm 0.03^{\mathrm{bc}}$ & $29.22 \pm 0.84^{\mathrm{gh}}$ & $9.97 \pm 0.21^{\mathrm{fg}}$ & $1.63 \pm 0.21^{\mathrm{abcd}}$ \\
\hline \multirow[t]{4}{*}{ April } & $\mathrm{Fl}$ & $0.16 \pm 0.06^{\mathrm{ab}}$ & $17.60 \pm 0.68^{\mathrm{ef}}$ & $8.35 \pm 0.79^{\mathrm{ef}}$ & $0.98 \pm 0.16^{\mathrm{abc}}$ \\
\hline & $\mathrm{Lv}$ & $0.36 \pm 0.01^{\text {defg }}$ & $38.97 \pm 0.91^{\mathrm{k}}$ & $16.96 \pm 0.51^{\mathrm{i}}$ & $3.95 \pm 1.31^{\mathrm{ef}}$ \\
\hline & St & - & $10.64 \pm 0.48^{\mathrm{bc}}$ & $3.70 \pm 0.23^{\mathrm{ab}}$ & $0.55 \pm 0.0 .29^{a}$ \\
\hline & $\mathrm{AP}$ & $0.30 \pm 0.02^{\text {cdef }}$ & $31.06 \pm 1.35^{\mathrm{hi}}$ & $11.05 \pm 0.42^{\mathrm{gh}}$ & $2.95 \pm 0.23^{\mathrm{de}}$ \\
\hline \multirow[t]{4}{*}{ May } & $\mathrm{Fl}$ & $0.21 \pm 0.03^{\mathrm{abc}}$ & $14.98 \pm 0.15^{\mathrm{de}}$ & $7.99 \pm 1.39^{\mathrm{def}}$ & $1.48 \pm 0.45^{\mathrm{abcd}}$ \\
\hline & $\mathrm{Lv}$ & $0.37 \pm 0.04^{\mathrm{efg}}$ & $41.63 \pm 0.96^{\mathrm{k}}$ & $20.91 \pm 0.16^{\mathrm{j}}$ & $5.86 \pm 0.83 \mathrm{f}^{\mathrm{g}}$ \\
\hline & St & - & $13.09 \pm 0.83^{\mathrm{cd}}$ & $6.91 \pm 0.63^{\text {cde }}$ & $0.73 \pm 0.26^{\text {abcde }}$ \\
\hline & AP & $0.41 \pm 0.02^{\mathrm{fg}}$ & $33.31 \pm 0.93^{\mathrm{ij}}$ & $10.08 \pm 1.19^{\mathrm{fg}}$ & $2.75 \pm 0.41^{\text {cde }}$ \\
\hline \multirow[t]{4}{*}{ June } & $\mathrm{Fl}$ & $0.26 \pm 0.04^{\text {bcde }}$ & $19.84 \pm 0.88^{\mathrm{f}}$ & $9.78 \pm 0.51^{\mathrm{fg}}$ & $1.68 \pm 0.18^{\mathrm{abcd}}$ \\
\hline & Lv & $0.45 \pm 0.01^{\mathrm{g}}$ & $45.35 \pm 1.35^{\mathrm{k}}$ & $24.03 \pm 0.85^{\mathrm{k}}$ & $5.24 \pm 0.64^{\mathrm{fg}}$ \\
\hline & St & - & $14.71 \pm 0.96^{\mathrm{de}}$ & $6.53 \pm 0.37^{\text {cde }}$ & $1.96 \pm 0.31^{\mathrm{abcd}}$ \\
\hline & $\mathrm{AP}$ & $0.38 \pm 0.08^{\mathrm{fg}}$ & $39.50 \pm 0.42^{\mathrm{k}}$ & $17.09 \pm 0.89^{\mathrm{i}}$ & $3.13 \pm 0.62^{\mathrm{de}}$ \\
\hline
\end{tabular}

Means within a column lacking a common superscript differ $(\mathrm{p}<0.05) .(-)$ : Not detected; Fl: Flower; Lv: Leave; St: Stem; AP: Aerial part; EO: Essential oil; TP: Total phenols content expressed as milligram gallic acid equivalents per g of sample; TT: Total tannins content expressed as milligram tannic acid equivalents per $\mathrm{g}$ of sample; CT: Condensed tannins content expressed as milligram catechin equivalents per $g$ of sample 
The average content of total phenols (TP) shows significant variability between different fractions of plants studied $(\mathrm{P}<0.05)$. Irrespective of the season, the TP content was highest in the leaves followed by aerial parts and flowers, but the lowest was found in stems. Significant differences were observed in the values of total tannins (TT) in various fractions of the plant. The maximum TT values were found in the leaves and the minimum values were indicated in stems.

The condensed tannins (CT) of different parts of $B$. cinerea plant indicated that the maximum $\mathrm{CT}$ value was found in leaves followed by the aerial parts, flowers and stems, respectively. There were no significant differences in the CT values of the different fractions of the plant. Results also demonstrated that the values of TT and CT content were low in younger plant tissues as compared to the mature tissues. The effect of harvest date revealed that the contents of these secondary metabolites studied were increased with the maturity of the plant which concord with studies carried out by Li et al. (2020).

The phenols and tannins are anti-nutritional substances that are involved in the defense mechanisms of the plant. The richness in EOs, TP, TT and CT content may be related to the adaptation model of $B$. cinerea as a response to stress (rarity rains, high temperatures and drought). The increased level of tannins can also reflect the protection of plants against attacks by pathogens microorganisms (fungi and bacteria) and predatory herbivores (folivorous animals or insects) (Mebirouk-Boudechiche et al. 2014).

The total phenols and tannins contained in the different parts of the plant could have a limited effect on the availability of their nutrients for ruminal microbiota due to the complexes they form with macromolecules, especially proteins and many types of molecules such as carbohydrates, minerals, enzymes and synthetic polymers which reduce its degradability (Zimmer and Cordesse 1996).

\section{In vitro dry matter digestibility (IVDMD)}

Monthly in vitro dry matter digestibility varied nonsignificantly during the study between various fractions of $B$. cinerea (Table 4). IVDMD of various parts of the $B$. cinerea plant indicated that the maximum value was found in leaves followed by flowers, while the lowest value of IVDMD was found in the stems. Results also demonstrated that the values of IVDMD were higher in younger aerial parts as compared to mature ones. The results obtained of IVDMD of $B$. cinerea were superior to those of plants grazed in Algeria, such as Neurada procumbens $(44,45 \pm$ 4,20\%), Aristida plumosa (47,45 \pm 4,34\%), Anabasis articulata $(45,96 \pm 364 \%)$ and Aristida pungens $(37,24 \pm$ $3,86 \%$ ) (Longo-Hammouda et al. 2007).

Holland et al. (2020) reported that as grass matures, the highly digestible leaf fraction of the plant becomes a smaller and less digestible component. Leaves contain less fiber and more CP than stems, and consequently are more digestible at all stages of development. However, with maturity, the leaf-to-stem ratio decreases, while the less digestible stem increases as a proportion of the plant and also decline in nutritive value as it matures (Azim et al. 1989; Sultan et al. 2007).

\section{Net energy for lactation (NEl)}

The NEl was strongly affected by plant maturation. It was showed a maximum in February and declined with the age of the plant in various fractions of $B$. cinerea $(\mathrm{p}<0.01)$ (Table 4). Young plant tissues are biochemically active capturing more energy, synthesizing higher protein and fat contents than older tissues (Farrukh and Jan 2009).

The nutritional value assessment shows that the highest $\mathrm{NEl}$ values were recorded in leaves, followed by aerial parts and flowers. However, the lowest values were obtained from stems fractions. The differences were statistically significant $(p<0.001)$ in various plant parts.

\section{Relationship between $B$. cinerea harvest period and quality}

The nutritional value of forage is generally judged on the basis of its potentially digestible nutrient content (mainly energy, nitrogen, and minerals) and on the absence of undesirable compounds (Givens et al. 2000).

In the present study, the positive correlation between $\mathrm{NDF}, \mathrm{ADF}$ and plant age at harvest observed is comparable to studies conducted elsewhere for other browse species (Azim et al. 1989; Hoffman et al. 1993; Kulivand and Kafilzadeh 2015). On the contrary, plant age at harvest was found to be negatively correlated $(\mathrm{P}<0.0001)$ to $\mathrm{CP}$ and IVDMD.

Table 4. Monthly in vitro dry matter digestibility and Net energy for lactation of different fractions of Brocchia cinerea at different stages of maturity (mean $\pm \mathrm{SD})$

\begin{tabular}{|c|c|c|c|}
\hline $\begin{array}{l}\text { Harvest } \\
\text { month }\end{array}$ & $\begin{array}{l}\text { Plant } \\
\text { fraction }\end{array}$ & \%IVDMD & NEl (Mcal/kg) \\
\hline \multirow[t]{4}{*}{ February } & $\mathrm{Fl}$ & $83.21 \pm 1.41^{\mathrm{h}}$ & $1.22 \pm 0.04^{\mathrm{j}}$ \\
\hline & Lv & $89.43 \pm 2.01^{\mathrm{fgh}}$ & $1.78 \pm 0.02^{\mathrm{hij}}$ \\
\hline & St & $72.16 \pm 0.37^{\text {cdef }}$ & $1.14 \pm 0.09^{\text {cde }}$ \\
\hline & AP & $79.68 \pm 0.48^{\mathrm{gh}}$ & $1.27 \pm 0.02^{\text {fgh }}$ \\
\hline \multirow[t]{4}{*}{ March } & $\mathrm{Fl}$ & $77.89 \pm 1.9^{\text {gh }}$ & $1.19 \pm 0.01^{\mathrm{j}}$ \\
\hline & Lv & $85.11 \pm 1.59^{\mathrm{fg}}$ & $1.34 \pm 0.04^{\mathrm{ghi}}$ \\
\hline & St & $69.65 \pm 0.68^{\text {bcde }}$ & $1.11 \pm 0.02^{\mathrm{cd}}$ \\
\hline & AP & $76.99 \pm 0.18^{\text {defg }}$ & $1.24 \pm 0.03^{\mathrm{fgh}}$ \\
\hline \multirow[t]{4}{*}{ April } & $\mathrm{Fl}$ & $73.80 \pm 1.71^{\mathrm{efg}}$ & $1.07 \pm 0.02^{\mathrm{efg}}$ \\
\hline & Lv & $83.12 \pm 0.18^{\mathrm{gh}}$ & $1.31 \pm 0.05^{\mathrm{ghi}}$ \\
\hline & St & $69.05 \pm 0.25^{\text {bcde }}$ & $0.99 \pm 0.01^{\mathrm{abc}}$ \\
\hline & AP & $73.38 \pm 0.66^{\text {cdef }}$ & $1.16 \pm 0.02^{\text {cde }}$ \\
\hline \multirow[t]{4}{*}{ May } & $\mathrm{Fl}$ & $70.84 \pm 2.11^{\text {cdef }}$ & $1.01 \pm 0.04^{\text {cdef }}$ \\
\hline & Lv & $82.01 \pm 0.55^{\mathrm{fgh}}$ & $1.22 \pm 0.01^{\mathrm{efg}}$ \\
\hline & St & $67.85 \pm 1.64^{\mathrm{abc}}$ & $0.97 \pm 0.08^{\mathrm{ab}}$ \\
\hline & AP & $68.75 \pm 1.49^{\mathrm{bcd}}$ & $1.12 \pm 0.02^{\mathrm{cd}}$ \\
\hline \multirow{4}{*}{ June } & $\mathrm{Fl}$ & $65.68 \pm 0.24^{\mathrm{abc}}$ & $0.94 \pm 0.01^{\text {cde }}$ \\
\hline & Lv & $76.85 \pm 1.49^{\text {defg }}$ & $1.16 \pm 0.1^{\mathrm{def}}$ \\
\hline & St & $59.56 \pm 1.27^{\mathrm{a}}$ & $0.83 \pm 0.08^{\mathrm{a}}$ \\
\hline & $\mathrm{AP}$ & $61.65 \pm 2.16^{\mathrm{ab}}$ & $1.07 \pm 0.03^{\mathrm{bc}}$ \\
\hline
\end{tabular}

Means within a column lacking a common superscript differ $(\mathrm{p}<0.05)$. Fl: Flower; Lv: Leave; St: stem; AP: Aerial part; IVDMD: In vitro dry matter digestibility; NEl: Net energy for lactation 
Leaves and flowers of $B$. cinerea were less fibrous than stems. NDF and ADF content were more abundant in stems, which also were more lignified than other parts of the plant. The variation in the fiber values could be attributed to age and/or the physical composition differences of the plant collected (Nampanzira et al. 2015; Nsubuga et al. 2019). Marshall et al. (1998) and Elgersma and Søegaard (2018) reported that as plants mature and sward height increases, NDF and ADF content increases, causing the nutritive value to decline.

The NDF $(r=-0.78, p=0.0001)$, ADF $(r=-0.77, p=$ $0.0001)$ and $\mathrm{ADL}(\mathrm{r}=-0.76, \mathrm{p}=0.0001)$ were negatively correlated with IVDMD in various plant parts. NDF was more difficult to digest than the non-fiber components of forage. Therefore, digestion slows dramatically as forage becomes more mature. This also influences forage consumption by animals (Ball et al. 2001). The findings of this study were in line with those of Sultan et al. (2007) who reported a negative correlation of NDF with digestibility.

An increase of parietal compounds (NDF, ADF and $\mathrm{ADL}$ ) is linked to the mode of adaptation to arid environments. Deinum and Dirven (1976) and Chehma et al. (2010) reports that the increase in temperature stimulates the lignification of the supporting tissues of plants. He et al. (2018) reported an increase in all-fiber constituents with increasing maturity, as they also reported that lignin was proportionately higher in the stem than in other parts of the plants.

The CP content had a positive correlation with IVDMD $(\mathrm{r}=0.78, \mathrm{p}=0.0001)$ and with $\mathrm{NEl}(\mathrm{r}=0.74, \mathrm{p}=0.0001)$ and negative correlation with NDF $(r=-0.70, p=0.0001)$, ADF $(\mathrm{r}=-0.56, \mathrm{p}=0.0001)$ and ADL $(\mathrm{r}=-0.76, \mathrm{p}=0.0001)$. These results supported the findings of Sultan et al. (2007) who reported that animals preferred food having higher $\mathrm{CP}$ contents. CP content in different organs of $B$. cinerea showed its maximum at the reproductive and flowering stage, but this content decreases with plant age and in warm weather months.

Soils of arid regions are known to be poor in organic matter and nitrogen. This negatively impacts the nutritive richness of the plants which inhabit them (Bouallala et al 2013). The TT content was positively correlated with NDF $(\mathrm{r}=0.22, \mathrm{P}=0.0001), \mathrm{ADF}(\mathrm{r}=0.38, \mathrm{P}=0.0001)$ and ADL $(\mathrm{r}$ $=0.50, \mathrm{P}=0.0001)$ and negatively correlated to $\mathrm{CP}(\mathrm{r}=-0.76$, $\mathrm{P}=0.0001)$, while $\mathrm{CT}$ content was negatively correlated with $\mathrm{CP}(\mathrm{r}=-0.52, \mathrm{P}=0.0001)$ and IVDMD $(\mathrm{r}=-0.65$, $\mathrm{P}=0.0001)$.

The tannins might have an inhibitory effect on protein digestion, either by direct enzyme inhibition or by forming relatively indigestible complexes with proteins, thus effectively reducing the nutritive value of the plants (Naumann et al. 2017). Similarly, tannins can bind to the forages fibers and thus limit their ruminal digestion. In this case, the digestion of fibers is definitively reduced since their degradation is carried out essentially in the rumen (Julier and Huyghe 2010).

The $\mathrm{CP}$ reduction and tannins increase can be attributed to the adaptation strategy of the plant in the drylands, which is why it develops thick cuticles and drought adaptation mechanisms to reduce evapotranspiration: these chemical components are mainly cytoplasmic and chlorophyllic contents (Chehma et al. 2010; Bouallala et al. 2011). Although nutrient composition varied with $B$. cinerea age, the quality remained relatively average. Lower fiber and higher protein contents can be expected during the cooler months, while higher fiber and lower protein can be expected in the summer months when environmental temperatures are warm (Marshall et al. 1998; Nardone et al. 2010).

Chemical composition differed from one plant organ to another. Leaves were richest in $\mathrm{CP}$, their DMD and NEl were high, especially during the cold months (February through April). Stems had high NDF, ADF, and ADL contents, a low $\mathrm{CP}$ content and its digestibility and NEl decreased with plant maturity. According to this study, the good nutritional quality of $B$. cinerea was noted when the animals grazed between February to April. This plant is among other grazed species that characterize the pastoral drylands of south-eastern Morocco, and that is potential medium quality roughage feeds that can meet the maintenance needs of some animals (Ball et al. 2001; Nsubuga et al. 2019).

Drylands are characterized by unfavorable climatic conditions for the development of fodder plants, which are of essential importance in supporting the basic nutritional requirements of ruminants in these regions. In this study, the results indicate that the nutritional quality and botanical composition of different parts of $B$. cinerea varied with harvest months. According to these analyses, all plant organs declined in CP and IVDMD and increased in NDF, $\mathrm{ADF}$ and $\mathrm{ADL}$ as maturity advanced, leading to a decline in nutritive value. $\mathrm{CP}$ was the major limiting nutrient in livestock diets, while it was identified in leaves with high contents compared to the other plant fractions, in which this plant can reveal its nutritive potential through its leaves during the wet and cold season, when several thousand animals were browsing in these regions.

Therefore, B. cinerea species present suitable options for inclusion in agro forestry-livestock production systems to improve the nutrition of livestock. However, further research on the domestication potential of this browse species and on the effect of feeding it on animal productivity is needed.

\section{REFERENCES}

Amata IA, Lebari T. 2011. Comparative evaluation of the nutrient profile of four selected browse plants in the tropics, recommended for use as non-conventional livestock feeding materials. Afr J Biotechnol 10 (64): 14230-14233. DOI: 10.5897/AJB11.2488.

AOAC. 1990. Official Methods of Analysis 15th ed. Association of Official Analytical Chemists. Washington, DC.

AOCS. 2005. Rapid determination of oil/fat utilizing high-temperature solvent extraction. Method Am 5-04. In: Firestone D (ed) Office Methods and Recommended Practices of American Oil Chemist's Society, 6th ed. American Oil Chemists Society, Champaign, IL.

Azim A, Naseer Z, Ali A. 1989. Nutritional evaluation of maize fodder at two different vegetative stages. Asian-Australas J Anim Sci 2 (1): 27 34. DOI: 10.5713 /ajas.1989.27.

Ball DM, Collins M, Lacefield GD, Martin NP, Mertens DA, Olson KE, Putnam DH, Undersander DJ, Wolf MW. 2001. Understanding 
Forage Quality. American Farm Bureau Federation Publication 1-01. Park Ridge, IL.

Berhe DH, Tanga AA. 2013. Nutritional evaluation of Ficus thonningii Blume leaves as ruminant livestock feed in the Ahferom district of Tigray, Ethiopia. Afr J Range For Sci 30 (3): 149-154. DOI: 10.2989/10220119.2013.765505.

Bettencourt EMV, Tilman M, Narciso V, Carvalho MLDS, Henriques PDDS. 2015. The livestock roles in the wellbeing of rura communities of Timor-Leste. Rev Econ Sociol Rural 53 (1): S063S080. DOI: 10.1590/1234-56781806-94790053s01005.

Borneo R, León AE, Aguirre A, Ribotta P, Cantero JJ. 2009. Antioxidant capacity of medicinal plants from the Province of Córdoba (Argentina) and their in vitro testing in a model food system. Food Chem 112 (3): 664-670. DOI: 10.1016/j.foodchem.2008.06.027.

Bouallala M, Chehma A, Bensetti M. 2011. Variation de la composition chimique de principales plantes broutées par le dromadaire du SudOuest Algérien. LRRD 23 (5): 1-9.

Bouallala M, Chehma A, Hamel F. 2013. Evaluation de la valeur nutritive de quelques plantes herbacées broutées par le dromadaire dans le Sahara nord-occidental algérien. LSJ 14 (1): 33-38.

Capstaff NM, Miller AJ. 2018. Improving the yield and nutritional quality of forage crops. Front Plant Sci 9 (535): 1-18. DOI :10.3389/fpls.2018.00535.

Chaudhary DP, Kumar A, Mandhania SS, Srivastava P, Kumar RS. 2012. Maize As Fodder? An Alternative Approach. Directorate of Maize Research, Pusa Campus, New Delhi, India.

Chehma A, Faye B, Bastianelli D. 2010. Valeurs nutritionnelles de plantes vivaces des parcours sahariens algériens pour dromadaires. Fourrages (Versailles) 204 : 263-268.

Chlif N, Diouri M, El Messaoudi N, Sbai A, Bentayeb A. 2021 Ethnobotanical and agronomical survey of Brocchia cinerea (Delile) Vis. plant used by people in the Figuig and Draa-Tafilalet regions, Morocco. J Pharm Pharmacogn Res 9 (5): 685-694.

Da Silva SCD, Sbrissia AF, Pereira LET. 2015. Ecophysiology of C4 forage grasses - Understanding plant growth for optimising their use and management. Agriculture 5 (3): 598-625. DOI 10.3390/agriculture5030598.

Deinum B, Dirve JGP. 1976. Climate, nitrogen and grass. 7. Comparison of production and chemical composition of Brachiaria ruziziensis and Setaria sphacelata grown at different temperatures. Neth J agric Sci 24 (1): 67-78. DOI: 10.18174/njas.v24i1.17166.

Distel RA, Arroquy JI, Lagrange S, Villalba JJ. 2020. Designing diverse agricultural pastures for improving ruminant production systems. Front Sustain Food Syst 4 (3): 1-18. DOI: $10.3389 /$ fsufs. 2020.596869 .

Elgersma A, Søegaard K. 2018. Changes in nutritive value and herbage yield during extended growth intervals in grass-legume mixtures: Effects of species, maturity at harvest, and relationships between productivity and components of feed quality. Grass Forage Sci 73 (1) 78-93. DOI: $10.1111 / \mathrm{gfs} .12287$.

Etse WJ, Annang TY, Ayivor JS. 2018. Nutritional composition of aquatic plants and their potential for use as animal feed: A case study of the Lower Volta Basin, Ghana. Biofarmasi J Nat Prod Biochem 16 (2): 99-112. DOI: 10.13057/biofar/f160205.

Farrukh H, Jan Durrani M. 2009. Nutritional evaluation of some forage plants from Harboi Rangeland, Kalat, Pakistan. Pak J Bot 41 (3): $1137-1154$

Ferreira EA, Abreu JGD, Martinez JC, Braz TGDS, Ferreira DP. 2018 Cutting ages of elephant grass for chopped hay production. Pesquisa Agropecuaria Tropical 48 (3): 245-253. DOI: 10.1590/198340632018v4851569.

Ganskopp D, Bohnert D. 2001. Nutritional dynamics of 7 northern Great Basin grasses. J Range Manag 54: 640-647 DOI: 10.2307/4003664.

Givens D, Iwen E, Awforf RF, Omed H. 2000. Forage Evaluation in Ruminant Nutrition. CABI Publishing. New York, USA. DOI 10.1079/9780851993447.0000.

He Y, Mouthier TMB, Kabel MA, Dijkstra J, Hendriks WH, Struik PC, Cone JW. 2018. Lignin composition is more important than conten for maize stem cell wall degradation. J Sci Food Agric 98 (1): 384 390. DOI: $10.1002 /$ jsfa.8630.

Herrero M, Grace D, Njuki J, Johnson N. 2012. The roles of livestock in developing countries. Animal 7 (1): 3-18. DOI: 10.1017/S1751731112001954.

Hoffman K, Muller LD, Fales SL, Holden LA. 1993. Quality evaluation and concentrate supplementation of rotational pasture grazed by lactating cows. J Dairy Sci 76 (9): 2651-2663. DOI: 10.3168/jds.S0022-0302(93)77601-8.

Holland C, Ryden P, Edwards CH, Grundy MML. 2020. Plant cell walls: impact on nutrient bioaccessibility and digestibility. Food 9 (2): 1-16. DOI : $10.3390 /$ foods 9020201 .

Julier B, Huyghe C. 2010. Quelles légumineuses fourragères (espèces et variétés) et quelles conduites pour améliorer l'autonomie protéique des élevages herbivores?. Innov Agron 11: 101-114.

Komarek AR, Robertson JB, Van Soest PJ. 1994. A comparison of methods for determining $\mathrm{ADF}$ using the filter bag technique versus conventional filtration. J Dairy Sci 77 (1): 114

Kulivand M, Kafilzadeh F. 2015. Correlation between chemical composition, kinetics of fermentation and methane production of eight pasture grasses. Acta Sci Anim Sci 37 (1): 9-14. DOI: 10.4025/actascianimsci.v37i1.24336.

Lawrence JP, Hrstich LN, Chan BG. 1986. The conversion of procyanidins and prodelphinidins to cyanidin and delphinidin. Phytochemistry 25 (1): 223-230. DOI: 10.1016/S00319422(00)94533-3.

Lee MA. 2018. A global comparison of the nutritive values of forage plants grown in contrasting environments. J Plant Res 131: 641-654. DOI: $10.1007 / \mathrm{s} 10265-018-1024-\mathrm{y}$

Li Y, Kong D, Fu Y, Sussman MR, Wu H. 2020. The effect of developmental and environmental factors on secondary metabolites in medicinal plants. Plant Physiol Biochem 148: 80-89. DOI: 10.1016/j.plaphy.2020.01.006.

Longo-Hammouda FH, Siboukheur OE, Chehma A. 2007. Aspects nutritionnels des pâturages les plus appréciés par Camelus dromedarius en Algérie. Cah Agric 16 (6): 477-483. DOI: 10.1684/agr.2007.0144

Makkar HPS, Blümmel M, Borowy NK, Becker K. 1993. Gravimetric determination of tannins and their correlations with chemical and protein precipitation methods. J Sci Food Agric 61 (2): 161-165. DOI: $10.1002 /$ jsfa.2740610205.

Marshall SA, Campbell CP, Buchanan-Smith JG. 1998. Seasonal changes in quality and botanical composition of a rotationally grazed grasslegume pasture in southern Ontario. Can J Anim Sci 78 (2): 205-210. DOI: 10.4141/A97-002.

Martin B, Verdier-Metz I, Buchin S, Hurtaud C, Coulon JB. 2005. How do the nature of forages and pasture diversity influence the sensory quality of dairy livestock products?. Anim Sci J 81 (2): 205-212. DOI: 10.1079/ASC50800205

McAdams B, Von Massow M, Gallant M, Hayhoe MA. 2019. A crossindustry evaluation of food waste in restaurants. J Foodserv Bus Res 22 (5): 449-466. DOI: 10.1080/15378020.2019.1637220.

Mebirouk-Boudechiche L, Cherif M, Boudechiche L, Sammar F. 2014. Teneurs en composés primaires et secondaires des feuilles d'arbustes fourragers de la région humide d'Algérie. Rev Med Vet 165 (11-12): 344-352.

Nampanzira DK, Kabasa JD, Nalule SA, Nakalembe I, Tabuti JRS. 2015. Characterization of the goat feeding system among rural small holder farmers in the semi-arid regions of Uganda. Springerplus 4 (1): 188. DOI : 10.1186/s40064-015-0961-3.

Nardone A, Ronchi B, Lacetera N, Ranieri MS, Bernabucci U. 2014. Effects of climate changes on animal production and sustainability of livestock systems. Livest Sci 130 (1-3): 57-69. DOI : 10.1016/j.livsci.2010.02.011.

Naumann HD, Teseschi LO, Zeller WE, Huntley NF. 2017. The role of condensed tannins in ruminant animal production: advances, limitations and future directions. R Bras Zootec 46: 929-949. DOI: 10.1590/S1806-92902017001200009.

Nelson DW, Sommers LE. 1972. A simple digestion procedure for estimation of total nitrogen in soils and sediments. J Environ Qual 1 (4): 423-425. DOI: 10.2134/jeq1972.00472425000100040020x.

NRC (National Research Council). 2001. Nutrient Requirements of dairy cattle. Seventh Revised Edition. Nutrient requirements of dairy cattle. National Academy Press, NRC, Washington DC

Nsubuga D, Nampanzira DK, Masembe C, Muwanika VB. 2019. Nutritional properties of some browse species used as goat feed in pastoral drylands, Uganda. Agrofor Syst 94 (3): 933-940. DOI: 10.1007/s10457-019-00452-x.

Oredice J, Smith RG, Carroll J, Asbjornsen H, Hpward T. 2019. Forage productivity and profitability in newly-established opes pasture, silvopasture, and thinned forest production systems. Agrofor Syst 93 (1): 51-65. DOI: 10.1007/s10457-016-0052-7. 
Rivero MJ, Rodríguez-Estévez V, Pietrosemoli S, Carballo C, Cooke AS Kongsted AG. 2019. Forage consumption and its effects on the performance of growing swine - discussed in relation to European wild boar (Sus scrofa L.) in semi-extensive systems: A review. Animals 9 (7): 457 . DOI: 10.3390/ani9070457

Sultan JI, Inam-Ur-Rahim, Yaqoob M, Nawaz H, Hameed M. 2007. Nutritive value of free rangeland grasses of northern grasslands of Pakistan. Pak J Bot 39 (4): 249-258.

Tilahun G, Asmare B, Mekuriam Y. 2017. Effects of harvesting age and spacing on plant characteristics, chemical composition and yield of desho grass (Pennisetum pedicellatum Trin.) in the highlands of Ethiopia. Trop Grassl 5 (2): 77-84. DOI: 10.17138/TGFT(5)77-84.

Velásquez AV, Martins CMMR, Pacheco P, Fukushima RS. 2019. Comparative study of some analytical methods to quantify lignin concentration in tropical grasses. Asian-Australas J Anim Sci 32 (11): 1686-1694. DOI: 10.5713/ajas.17.0450.

Walthall CL, Hatfield J, Backlund P, Lengnick L, Marshall E, Walsh M, Adkins S, Aillery M, Ainsworth EA, Ammann C, Anderson CJ, Bartomeus I, Baumgard LH, Booker F, Bradley B, Blumenthal DM,
Bunce J, Burkey K, Dabney SM, Delgado JA, Dukes J, Funk A, Garrett K, Glenn M, Grantz DA, Goodrich D, Hu S, Izaurralde RC, Jones RAC, Kim SH, Leaky ADB, Lewers K, Mader TL, McClung A, Morgan J, Muth DJ, Nearing M, Oosterhuis DM, Ort D, Parmesan C, Pettigrew WT, Polley W, Rader R, Rice C, Rivington M, Rosskopf E, Salas WA, Sollenberger LE, Srygley R, Stöckle C, Takle ES, Timlin D, White JW, Winfree R, Wright-Morton L, Ziska LH. 2012. Climate change and agriculture in the United States: Effects and adaptation. USDA Techn. ed, Paper Knowledge. Toward a Media History of Documents, Washington, DC.

Xie ZL, Zhang T F, Chen XZ, Li GD, Zhang JG. 2012. Effects of maturity stages on the nutritive composition and silage quality of whole crop wheat. Asian-Australas J Anim Sci 25 (10): 1374-1380. DOI: 10.5713/ajas.2012.12084

Zimmer N, Cordesse R. 1996. Influence des tanins sur la valeur nutritive des aliments pour ruminants. INRA Prod Anim 9 (3): 167-179. DOI: 10.20870/productions-animales. 1996.9.3.4044. 